\title{
US-Berufungsgericht lässt Klage gegen die Stiftung Preussischer Kulturbesitz (SPK) auf Herausgabe des Welfenschatzes zu
}

\author{
United States Court of Appeals (For the District of Columbia Circuit)
}

Argued May 2, 2018 | Decided July 10 | 2018, No. 17-7064

Alan Philipp, et al. (Appellees) v. Federal Republic of Germany and Stiftung Preussischer Kulturbesitz (Appellants)

\section{Consolidated with 17-7117}

Appeals from the United States District Court for the District of Columbia

(No. 1:15-cv-00266)

Jonathan $M$. Freiman argued the cause for appellants. With him on the briefs were Benjamin M. Daniels, David R. Roth and David L. Hall.

Nicholas M. O'Donnell argued the cause and filed the brief for appellees.

Gary A. Orseck, Ariel N. Lavinbuk, Daniel N. Lerman and D. Hunter Smith were on the brief for amicus curiae David Toren in support of appellees.

Before: Tatel, Griffith, and Wilkins, Circuit Judges.

Opinion for the Court filed by Circuit Judge Tatel.

Tatel, Circuit Judge: In this case, the heirs of several Jewish art dealers doing business in Frankfurt, Germany in the 1930s seek to recover a valuable art collection allegedly taken by the Nazis. Defendants, the Federal Republic of Germany and the agency that administers the museum where the art is now exhibited, moved to dismiss, claiming immunity from suit under the Foreign Sovereign Immunities Act. They also argued that the heirs failed to exhaust their remedies in German courts and that their state-law causes of action are preempted by United States foreign policy. The district court rejected all three arguments and denied the motion to dismiss. For the reasons set forth below, we largely affirm.

\section{I.}

Because this appeal comes to us from the district court's ruling on a motion to dismiss, "we must accept as true all material allegations of the complaint, drawing all reasonable inferences from those allegations in plaintiffs' favor." de Csepel v. Republic of Hungary, 714 F.3d 591, 597 (D.C. Cir. 2013) (internal quotation marks omitted). Viewed through that lens, the complaint relates the following events:
In 1929, three Frankfurt-based firms owned by Jewish art dealers joined together into a "Consortium" and purchased "a unique collection of medieval relics and devotional art" called the Welfenschatz. First Amended Compl. (FAC) ๆ 1, Philipp v. Federal Republic of Germany, 248 F. Supp. 3d 59 (D.D.C. 2017) (No. 1:15-cv-00266); see id. ๆๆ 34-35. The treasure - or "schatz" - acquired its name due to its association with the House of Welf, an ancient European dynasty. See id. ๆ 30.

Dating primarily from the eleventh to fifteenth centuries, the several dozen pieces that make up the Welfenschatz were housed for generations in Germany's Brunswick Cathedral. See id. After displaying the Welfenschatz throughout Europe and the United States and selling a few dozen pieces, the Consortium placed the remainder of the collection, which at that time retained about eighty percent of the full collection's value, into storage in Amsterdam. Id.१ๆ 41, 78.

The heirs allege that "[a]fter the [1933] Nazi-takeover of power in Germany, ... the members of the Consortium faced catastrophic economic hardship,"id. ๆ 10, and in 1935, following "two years of direct persecution" and "physical peril to themselves and their family members," id. If 145, the Consortium sold the Welfenschatz to the Nazi-controlled State of Prussia for 4.25 million Reichsmarks (the German currency at the time), id. ๆๆ 145160 , "barely $35 \%$ of its actual value," id. ๆ 12. "Standing behind all of this was [Hermann] Goering," id. १ 73, "Prime Minister of Prussia at that time," id., a "notorious racist and anti-Semite," id. ๆ 74, and "legendary" art plunderer, id. ๆ 75. Goering "seldom if ever" seized outright the art he desired, preferring "the bizarre pretense of 'negotiations' with and 'purchase' from counterparties with little or no ability to push back without risking their property or their lives." Id. The Welfenschatz was then shipped from Amsterdam to Berlin, see id. ๆ 157, where Goering presented it to Adolf Hitler as a "surprise gift," id. $\uparrow 179$ (quoting Hitler Will Receive \$2,500,000 Treasure, Balt. Sun, Oct. 31, 1935, at 2). All but one of the Consortium members then fled the country. See id. ๆๆ 163, 170-171. The remaining member died shortly after, officially of "cardiac insufficiency," id. ๆ 163, but "rumors" circulated that he was "dragged to his death through the streets of Frankfurt by a Nazi mob," id. ๆ 166.

"After the war, [the Welfenschatz] was seized by U.S. troops," id. I 181, and eventually turned over to appellant Stiftung Preussischer Kulturbesitz (SPK), a German agency formed "for the purpose ... of succeeding to all of Prussia's rights in cultural property," id. ๆ 184; see id. ๆๆ 181-84. The Welfenschatz is now exhibited in an SPK-administered museum in Berlin. Id. 9 26(iv). 
In 2014, appellees, Alan Philipp, Gerald Stiebel, and Jed Leiber, heirs of Consortium members, sought to recover the Welfenschatz, and they and the SPK agreed to submit the claim to a commission that had been created pursuant to the Washington Conference Principles on Nazi-Confiscated Art, id. I 220, an international declaration that "encouraged" nations "to develop ... alternative dispute resolution mechanisms for Nazi-era art claims, id. 1197 (quoting U.S. Dep't of State, Washington Conference Principles on Nazi-Confiscated Art 11 (1998) [hereinafter Washington Principles]). Known as the German Advisory Commission for the Return of Cultural Property Seized as a Result of Nazi Persecution, Especially Jewish Property, id. I 205, the Advisory Commission concluded "that the sale of the Welfenschatz was not a compulsory sale due to persecution" and it therefore could "not recommend the return of the Welfenschatz to the heirs," Advisory Commission, Recommendation Concerning the Welfenschatz (Guelph Treasure) (Mar. 20, 2014), Appellant s' Supp. Sources 7; see also FAC ๆ 221.

Seeking no further relief in Germany, the heirs filed suit in the United States District Court for the District of Columbia against the Federal Republic of Germany and the SPK (collectively, "Germany"), asserting several common-law causes of action, including replevin, conversion, unjust enrichment, and bailment. See FAC ๆ $250-304$. They sought the return of the Welfenschatz "and/or" 250 million dollars, id. Prayer for Relief, a "conservative estimate[]" of its value, id. ๆ 33. Germany moved to dismiss, arguing that it enjoyed immunity from suit under the Foreign Sovereign Immunities Act (FSIA), that international comity required the court to decline jurisdiction until the heirs exhaust their remedies in German courts, and that United States foreign policy preempted the heirs' state-law causes of action. The district court rejected all three arguments and, aside from a few uncontested issues, denied the motion to dismiss. Philipp, 248 F. Supp. $3 d$ at 87.

Germany appealed the district court's FSIA determination as of right. See Owens v. Republic of Sudan, 531 F.3d 884, 887 (D.C. Cir. 2008) ("[W]hen . . a denial [of a motion to dismiss] subjects a foreign sovereign to jurisdiction, the order is 'subject to interlocutory appeal.'" (quoting El-Hadad v. United Arab Emirates, 216 F.3d 29, 31 (D.C. Cir.2000))). On Germany's motion, the district court certified the other two issues for interlocutory appeal, Philipp v. Federal Republic of Germany, 253 F. Supp. 3d 84 (D.D.C. 2017), and this court granted Germany's petition to present them now, Per Curiam Order, In re Federal Republic of Germany, No. 17-8002 (D.C. Cir. Aug. 1, 2017). Reviewing de novo, we address Germany's immunity, comity, and preemption arguments in turn.

\section{II.}

Under the FSIA, foreign sovereigns and their agencies enjoy immunity from suit in United States courts unless an expressly specified exception applies. 28 U.S.C. § 1604. The heirs assert jurisdiction under the statute's "expropriation exception," see id. § 1605(a)(3), which "has two requirements": that "'rights in property taken in violation of international law are in issue,"' and that "there is an adequate commercial nexus between the United States and the defendant[]," de Csepel v. Republic of Hungary, 859 F.3d 1094, 1101 (D.C. Cir. 2017) (quoting 28 U.S.C. $\S 1605(a)(3))$. Germany "bears the burden of proving that [the heirs'] allegations do not bring [the] case within" the exception. Phoenix Consulting Inc. v. Republic of Angola, 216 F.3d 36, 40 (D.C. Cir. 2000).

A.

As to the expropriation exception's first requirement, we explained in Simon v. Republic of Hungary, 812 F.3d 127 (D.C. Cir. 2016), that although an "intrastate taking" - a foreign sovereign's taking of its own citizens' property - does not violate the international law of takings, id. at 144 , an intrastate taking can nonetheless subject a foreign sovereign and its instrumentalities to jurisdiction in the United States where the taking "amounted to the commission of genocide," id.at 142. This, we explained, is because "[g]enocide perpetrated by a state," even "against its own nationals[,] . . . is a violation of international law." Id.at 145. In so holding, we adopted the definition of genocide set forth in the Convention on the Prevention of the Crime of Genocide. Id.at 143. "[A]dopted by the United Nations in the immediate aftermath of World War II," id., the Convention defines genocide, in relevant part, as "[d]eliberately inflicting" on "a national, ethnical, racial or religious group ... conditions of life calculated to bring about its physical destruction in whole or in part," Convention on the Prevention and Punishment of the Crime of Genocide (Genocide Convention), art. 2, Dec. 9, 1948, 78 U.N.T.S. 277.

In Simon, "survivors of the Hungarian Holocaust," 812 F.3d at 134 , alleged that in 1944-45 Hungary "forced all Jews into ghettos, ... confiscating Jewish property" in the process, id.at 133, and then "transport[ed] Hungarian Jews to death camps, and, at the point of embarkation, confiscate[d] [their remaining] property," id.at 134. Assuming the truth of these allegations - like here, the case came to us from a ruling on a motion to dismiss we held that because the allegations of "systematic, whole sale plunder of Jewish property ... aimed to deprive Hungarian Jews of the resources needed to survive as a people... describe[d] takings of property that are themselves genocide within the legal definition of the term," id. at 14 3-44 (internal quotation marks omitted), they "fit[] squarely within the terms of the expropriation exception," id.at 146.

A year later, in de Csepel v. Republic of Hungary, 859 F.3d 1094 (D.C. Cir. 2017), we considered claims by the heirs of a Jewish collector whose art was seized by the "Hungarian government and its Nazi collaborators," id.at 1097. We held, among other things, that plaintiffs could pursue their "bailment" claim for return of the art. Id.at 1103. The case, we explained, was "just like Simon." Id. at 1102. "Here, as there, Hungary seized Jewish property during the Holocaust. Here, as there, plaintiffs bring ' 
garden-variety common-law' claims to recover for that taking." Id.

In today's case, the heirs argue that, after Simon and de Csepel, "[i]t is beyond serious debate that Nazi Germany took property in violation of international law by systematically targeting its Jewish citizens to make their property vulnerable for seizure." Appellees' Br. 27. The district court agreed, concluding that, "like in Simon, the taking of the Welfenschatz as alleged in the complaint bears a sufficient connection to genocide such that the alleged coerced sale may amount to a taking in violation of international law." Philipp, 248 F. Supp. 3d at 71. Germany disagrees, insisting that "[t]he allegations here have little in common with the Simon allegations except that they happened under Nazi rule." Appellants' Br. 35. According to Germany, four differences between this case and Simon compel a different result.

First, Germany argues that unlike in Simon, where the Nazis confiscated "food, medicine, clothing, [or] housing," here they seized art. Id.at 40. Although de Csepel also involved a seizure of art, we had no need to decide then whether Simon applied because the Hungarian government had conceded that the seizure there was genocidal, see de Csepel v. Republic of Hungary, 169 F. Supp. 3d 143, 164. (D.D.C. 2016). Thus, we are asked for the first time whether seizures of art may constitute "takings of property that are themselves genocide." Simon, 812 F.3d at 144 (emphasis omitted). The answer is yes.

Congress has twice made clear that it considers Nazi art-looting part of the Holocaust. In enacting the Holocaust Victims Redress Act, which encouraged nations to return Nazi-seized assets, Congress "f[ound]" that "[t]he Nazis' policy of looting art was a critical element and incentive in their campaign of genocide against individuals of Jewish ... heritage." Holocaust Victims Recovery Act, Pub. L. No. 105-158, § 201, 112 Stat. 15, 15 (1998). And in the Holocaust Expropriated Art Recovery Act (HEAR Act), which extended statutes of limitation for Nazi artlooting claims, Congress again "f[ound]" that "the Nazis confiscated or otherwise misappropriated hundreds of thousands of works of art and other property throughout Europe as part of their genocidal campaign against the Jewish people and other persecuted groups." Holocaust Expropriated Art Recovery Act of 2016, Pub. L. No. 114-308, § 2, 130 Stat. 1524, 1524 (emphasis added).

In this case, moreover, the Welfenschatz was more than just art. As Germany acknowledges, "the Consortium bought [the Welfenschatz] not for pleasure or display, but as business inventory, to re-sell for profit." Appellants' Br. 12. By seizing businesses' inventory - like the other economic pressures alleged in the complaint, such as the "boycott of Jewish-owned businesses," FACף 58, and "exclu[sion]" of Jews from certain professions, id. ๆ 120 - the Nazis "dr[ove] Jews out of their ability to make a living," id. 61 , and thereby, in the words of the Genocide
Convention, "inflict[ed]. . . conditions of life calculated to bring about [a group's] physical destruction in whole or" - at the very least - "in part," Genocide Convention art. 2(c).

Second, Germany argues that whereas Simon involved a "forcible deprivation" of property, Appellants' Br. 40, this case involves only a "forced sale ... for millions of Reichsmarks," id. at 42. For purposes of this appeal, however, Germany concedes that the forced sale qualifies as a "tak[ing]," id. at 28 n.12, and it offers no reason why a taking by forced sale cannot qualify as a genocidal taking. Indeed, the heirs' allegations - allegations that, we repeat, we must accept as true at this stage of the litigation - support just that conclusion. According to the complaint, Goering "routinely went through the bizarre pretense of 'negotiations' with and 'purchase' from" powerless counterparties. FAC १ 75. In addition, the heirs allege, the Nazis made it impossible for Jewish dealers to sell their art on the open market. Jewish art dealers' "means of work" were "effectively end[ed]," and "[m]ajor dealers' collections were liquidated because they could not legally be sold." Id. ๆ 120. "Jewish art dealers ... lost" even "their Jewish customers," because, as a result of the crippling economic policies, "there was no money left to buy art." Id. ๆ 124. "By spring of 1935," the heirs allege, "the exclusion of Jews from ... German life ... had become nearly total. The means by which German art could be sold by Jewish dealers had effectively been eliminated." Id. 9138 . It was within that context, the heirs allege, that the Nazis pressured the Consortium to sell the Welfenschatz for well below market value. Id. ๆ 139. "The Consortium had," the heirs allege, "only one option." Id. ๆ 145. 10 Fearful of losing the entire value of their property, or worse, the Consortium acquiesced. Id. $\uparrow 139$.

Third, Germany claims that "conditions for Hungarian Jews in 1944-45" - the period of time at issue in both Simon and de Csepel - "were far different from conditions for German Jews nearly a decade earlier, in the summer of 1935." Appellants' Br. 40 n.23. The sale of the Welfenschatz, Germany points out, predated "the Nuremberg Laws, ... the Decree on the Elimination of the Jews from Economic Life ..., and ... the mass murder of German Jews." Id.

In Simon, however, we explained that the "Holocaust proceeded in a series of steps." Simon, 812 F.3d at 143. "The Nazis . .. achieved [the Final Solution] by first isolating [the Jews], then expropriating the Jews' property, then ghettoizing them, then deporting them to the camps, and finally, murdering the Jews and in many instances cremating their bodies."' Id.at 144 (alterations in original) (quoting Complaint 9 91, Simon v. Republic of Hungary, 37 F. Supp. 3d 381 (D.D.C. 2014) (No. 1:10-cv-1770)). Although the events at issue in Simon occurred at the later steps of the Holocaust, i.e., ghettoization and deportation, and the events at issue here occurred at the earlier steps, i.e., isolation and expropriation, both are "steps" of the Holocaust, id. at 143. And, as the heirs allege, those earlier steps began as early as 1933, more than two years before the Nazis seized the Welfenschatz. Specifically, the heirs allege that the Nazis rose to power 
in the early 1930s by "blam[ing] Jews for any and all economic setbacks," FAC ף 48, and once in power, "encourage[d]" the "boycotts of Jewish businesses [that] spread in March and April 1933, just weeks after Hitler's ascension," id. ๆ 58. Moreover, the 1933 "found[ing] [of] the Reich Chamber of Culture," which "assumed total control over cultural trade" and excluded Jews, "effectively end[ed] the means of work for any Jewish art dealer in one stroke." Id. \ 120. The heirs also allege that outright violence against German Jews began several years before the seizure, including that "[b]y the spring $1933, \ldots$ the murder of Jews detained [in the Dachau concentration camp] went unprosecuted." Id. 59.

Moreover, in two statutes dealing with Nazi-era art-looting claims, Congress has expressly found that the Holocaust began in 1933. In the first statute - the very section of the FSIA at issue here - Congress provided jurisdictional immunity for certain art exhibition activities, 28 U.S.C. § 1605(h), but created an exception for art taken during the "Nazi[] era," defined as beginning in January 1933, id. § 1605(h)(2) (A). In the second, the HEAR Act, Congress again defined January 1933 as the beginning of the Nazi era. HEAR Act $\S 4$ (defining "covered period" as "beginning on January 1, 1933").

The heirs' position finds further support in a timeline on the website of the United States Holocaust Memorial Museum, which Germany itself cites for its observation that the taking of the Welfenschatz predated the Nuremburg Laws. See Appellants' Br. 40 n.23. That same timeline demonstrates that, by the time of the taking in 1935, the Nazi government had already opened the Dachau concentration camp, excluded Jews from all civil-service positions, and organized a nationwide boycott of Jewish-owned businesses.

Fourth, emphasizing that the definition of genocide includes an "intent to destroy," Genocide Convention art. 2(c) (emphasis added), Germany argues that this case differs from Simon because unlike there, where the plaintiffs alleged that the takings were "aimed to deprive Hungarian Jews of the resources needed to survive as a people," Simon, 812 F.3d at 143, here the heirs allege that the Nazis wanted the Welfenschatz because it was "historically, artistically and national-politically valuable," FAC 9111 . Elsewhere in the complaint, however, the heirs make clear that "[the Nazis] took the collection from [the Consortium] in order to 'Aryanize' [it]." Id. ๆ 25(iv). More specifically, the heirs allege that "the collection was wrongfully appropriated not least because [the Consortium members] were regarded as state's enemies for holding the iconic Welfenschatz," id. १ 25(ii), that "the Gestapo[] opened files on the members of the Consortium because of their ownership of the Welfenschatz and their prominence and success," id. 1 67, and that" Prussian interest in the Welfenschatz was. . . revived ... [once] the Consortium was .. .vulnerable," id. ๆ 68. In short, the heirs have sufficiently alleged that in seizing the Welfenschatz the Nazis were motivated, at least in part, by a desire "to deprive [German] Jews of the resources needed to survive as a people." Simon, 812 F.3d at 143.
Finally, unable to demonstrate that this case falls outside Simon's reach, Germany warns that allowing this suit to go forward will "dramatically enlarge U.S. courts' jurisdiction over foreign countries' domestic affairs" by stripping sovereigns of their immunity for any litigation involving a "transaction from 1933-45 between" a Nazi-allied government and "an individual from a group that suffered Nazi persecution." Appellants' Br. 4243. But as we have just explained, our conclusion rests not on the simple proposition that this case involves a 1935 transaction between the German government and Jewish art dealers, but instead on the heirs specific - and unchallenged - allegations that the Nazis took the art in this case from these Jewish collectors as part of their effort to "drive[] [Jewish people] out of their ability to make a living." FAC 9 61. Because Germany has failed to carry its burden of demonstrating that these allegations do not bring the case within the expropriation exception as defined and applied in Simon, the district court properly denied Germany's motion to dismiss.

\section{$B$.}

In Simon we held that, with respect to foreign states (but not their instrumentalities), the expropriation exception's second requirement - "an adequate commercial nexus between the United States and the defendant[]," de Csepel, 859 F.3d at 1101 - is satisfied only when the property is present in the United States. Simon, 812 F.3d at 146. Because the Simon plaintiffs had offered but a "bare, conclusory assertion" to that effect, we dismissed the Republic of Hungary from the action. Id. at 148. We faced the same issue in de Csepel because the art at issue there was not in the United States. de Csepel, 859 F.3d at 1107. Bound by Simon, we again dismissed the Republic of Hungary. Id.

Relying on Simon and de Csepel, Germany argues that because the Welfenschatz is in Berlin, not the United States, the Federal Republic of Germany must be dismissed. Although the heirs initially urged us to "reverse course on th[is] question," Appellees' Br. 34, as they acknowledged at oral argument, this panel is bound by Simon and de Csepel, Oral Arg. 50:14-40. Accordingly, on remand, the district court must grant the motion to dismiss with respect to the Federal Republic of Germany but not the SPK, an instrumentality for which the commercialnexus requirement can be satisfied without the presence of the Welfenschatz in the United States. See de Csepel, 859 F.3d at 1007 (explaining that "an agency or instrumentality loses its immunity if" the agency or instrumentality owns or operates the property at issue and is engaged in commercial activity in the United States).

\section{III.}

In Simon, we left open the question whether a court, despite having jurisdiction over an expropriation claim, "nonetheless should decline to exercise [it] as a matter of international comity unless the plaintiffs first exhaust domestic remedies (or demonstrate that they need not do so)." Simon, 812 F.3d at 149. In 
arguing that the answer to that question is yes, Germany does not claim, as it did in the district court, that we should defer to the Advisory Commission's refusal to recommend the return of the Welfenschatz, see Philipp, 248 F. Supp. 3d at 81. Instead, Germany argues that the heirs must "exhaust [their] remedies against [Germany] in [its] courts before pressing a claim against it elsewhere." Appellants' Br. 65. "'[B]ypass[ing] [its] courts,'” Germany insists, would "undermine [its] 'dignity [as] a foreign state.'" Id.at 68 (quoting Republic of Philippines v. Pimentel, 553 U.S. 851,866 (2008)). The district court rejected this argument, as do we.

The key case is the Supreme Court's decision in Republic of Argentina v. NML Capital, Ltd., 134 S. Ct. 2250 (2014), where Argentina claimed immunity from post-judgment discovery as a matter of international comity. The Court rejected that claim because nothing in the FSIA's plain text provided for such immunity. Id.at 2255. As the Court explained, although courts once decided on a case-by-case basis whether to grant foreign states immunity as matter of international comity, "Congress abated the bedlam in 1976, replacing the old executive-driven, factorintensive, loosely common-law-based immunity regime with the [FSIA]'s 'comprehensive set of legal standards governing claims of immunity in every civil action against a foreign state."' Id. (quoting Verlinden B.V. v. Central Bank of Nigeria, 461 U.S. 480, 488 (1983)). "[A]fter the enactment of the FSIA," the Court continued, "the Act - and not the pre-existing common law - indisputably governs the determination of whether a foreign state is entitled to sovereign immunity." Id.at 2256 (quoting Samantar v. Yousuf, 560 U.S. 305, 313 (2010)). Going forward, "any sort of immunity defense made by a foreign sovereign in an American court must stand on the Act's text. Or it must fall." Id.

Acknowledging that nothing in the text of the FSIA's expropriation exception requires exhaustion, Germany argues that applying NML Capital here "confuses immunity from jurisdiction with non-immunity common-law doctrines." Appellants' Reply Br. 38. The FSIA, Germany points out, operates as a passthrough, "granting jurisdiction yet leaving the underlying substantive law unchanged." Id. at 39 (quoting Owens v. Republic of Sudan, 864 F.3d 751, 763 (D.C. Cir. 2017)). As Germany emphasizes, FSIA section 1606 provides that foreign states not entitled to immunity, "shall be liable in the same manner and to the same extent as a private individual under like circumstances." Id. at 38 (quoting 28 U.S.C. § 1606). According to Germany, "exhaustion is a non-jurisdictional common-law doctrine," that, like forum non conveniens, "'remains fully applicable in FSIA cases."' Id.at 39 (quoting Price v. Socialist People's Libyan Arab Jamahiriya, 294 F.3d 82, 100 (D.C. Cir. 2002)).

Germany's effort to circumvent NML Capital fails for several reasons. To begin with, although a different provision of the FSIA, its terrorism exception, conditions jurisdiction on the claimant "afford[ing] the foreign state a reasonable opportunity to arbitrate the claim," 28 U.S.C. $§ 1605 A(a)(2)(A)(i i i)$, no such requi- rement appears in the expropriation exception, and we have long recognized "the standard notion that Congress's inclusion of a provision in one section strengthens the inference that its omission from a closely related section must have been intentional," Agudas Chasidei Chabad of U.S. v. Russian Federation, 528 F.3d 934, 948 (D.C. Cir. 2008). Moreover, far from demonstrating that the FSIA leaves room for an exhaustion requirement, the very FSIA provision that Germany relies on, section 1606, forecloses that possibility. By its terms, that provision permits only defenses, such as forum non conveniens, that are equally available to "private individual[s]," 28 U.S.C. § 1606. Obviously a "private individual" cannot invoke a "sovereign's right to resolve disputes against it." Appellants' Br. 68 (emphasis added).

To be sure, the Seventh Circuit, in a case similar to Simon, required the plaintiffs - survivors of the Hungarian Holocaust and the heirs of other victims - to "exhaust any available Hungarian remedies or [show] a legally compelling reason for their failure to do so," Fischer v. Magyar Allamvasutak Zrt., 777 F.3d 847, 852 (7th Cir. 2015). In doing so, the court distinguished NML Capital, holding that "defendants need not rely on ... the FSIA," but may "invoke the well-established rule that exhaustion of domestic remedies is preferred in international law as a matter of comity." Id. at 859. The Seventh Circuit drew that "wellestablished rule" from a provision of the Third Restatement of Foreign Relations Law of the United States, but as this court has explained, that "provision addresses claims of one state against another," Agudas Chasidei Chabad of U.S. v. Russian Federation, 528 F.3d 934, 949 (D.C. Cir. 2008). Confirming that interpretation, the tentative draft of the Fourth Restatement explains that "the rule cited by the [Seventh Circuit] applies by its terms to 'international ... proceedings,'" Restatement (Fourth) of Foreign Relations Law of the United States $\S 455$ Reporters' Note 9 (Am. Law Inst., Tentative Draft No. 2, 2016) - i.e., "nation vs. nation litigation," Chabad, 528 F.3d at 949; see also Agudas Chasidei Chabad of U.S. v. Russian Federation, 466 F. Supp. 2d 6, 21 (D.D.C. 2006) (" $[T]$ his court is not willing to make new law by relying on a misapplied, non-binding international legal concept."). And as we explained above, the FSIA, Congress's "comprehensive" statement of foreign sovereign immunity, which "is, and always has been, a 'matter of grace and comity," NML Capital, 134 S.Ct. at 2255 (quoting Verlinden, 461 U.S. at 486), leaves no room for a common-law exhaustion doctrine based on the very same considerations of comity.

In so concluding, we have considered the contrary position advanced by the United States in an amicus brief recently filed before a different panel of this court, where it argued that " $[t]$ he fact [that] the FSIA itself does not impose any exhaustion requirement for expropriation claims ... does not foreclose dismissal on international comity grounds." Brief of United States as Amicus Curiae at 14-15, Simon v. Republic of Hungary, No. 17-7146 (D.C. Cir. June 1, 2017). This position, of course, is flatly inconsistent with NML Capital, a case the government fails to 
cite, relying instead on non-FSIA cases, see id.at 15. Accordingly, nothing in the government's brief alters our conclusion that the heirs have no obligation to exhaust their remedies in Germany.

Germany protests that, as a "staunch U.S. ally," it "deserves the chance to address [the heirs'] attacks" in its own courts. Appellants' Br. 77. As the Court made clear in NML Capital, however, such "apprehensions are better directed to that branch of government with authority to amend the [FSIA]." NML Capital, 134 S. Ct. at 2258.

\section{IV.}

This brings us, finally, to Germany's argument that the heirs' state-law causes of action - replevin, conversion, unjust enrichment, and bailment - conflict with, and thus are preempted by, United States foreign policy. In support, Germany cites the Washington Principles, which "encouraged" nations "to develop ... alternative dispute-resolution mechanisms for resolving ownership issues," Washington Principles $\mathbb{1 1}$, as well the Terezin Declaration, a follow-up agreement also urging alternative dispute resolution. According to Germany, "letting [the heirs] press [the] same claims" they already presented to the Advisory Commission "again in a U.S. court" may cause signatories to the Washington Principles to "question whether [they] should follow the [] Principles," thereby "undermin[ing] the considerable diplomatic effort that the U.S. devoted to them." Appellants' Br. 56-57.

Germany relies principally on two cases, American Insurance Association v. Garamendi, 539 U.S. 396 (2003), and Crosby v. National Foreign Trade Council 530 U.S. 363 (2000). In Garamendi, the Supreme Court began by reiterating the basic rule that "at some point an exercise of state power that touches on foreign relations must yield to the National Government's policy, given the 'concern for uniformity in this country's dealings with foreign nations' that animated the Constitution's allocation of the foreign relations power to the National Government in the first place." Garamendi, 539 U.S. at 413 (quoting Banco Nacional de Cuba v. Sabbatino, 376 U.S. 398, 427 n.25 (1964)). Applying that rule to the facts of the case before it, the Court found California's attempt to regulate Holocaust-era insurance claims preempted by "the foreign policy of the Executive Branch, as expressed principally in ... executive agreements with Germany, Austria, and France." Id. In those executive agreements, the United States had "promised to use its 'best efforts, in a manner it considers appropriate,' to get state and local governments to respect [an internal dispute resolution process] as the exclusive mechanism.'" Id. at 406 (quoting Agreement Concerning the Foundation "Remembrance, Responsibility and the Future," Ger.-U.S., July 17, 2000, 39 I.L.M. 1298, 1300). In particular, the United States agreed that in any case involving Holocaust-era insurance claims, it would submit a statement "that U.S. policy interests favor dismissal on any valid legal ground." Id. (quoting Agreement Concerning the Foundation "Remembrance, Responsibility and the Future," 39 I.L.M.at 1304). Acknowledging that the executive agreements contained no preemption clause, the Court nonetheless concluded that the "express federal policy and the clear conflict raised by the [California] statute. . require[d] state law to yield." Id.at 425.

Similarly, in Crosby, the Court found Massachusetts's regulation of commerce with Burma to be "an obstacle to the accomplishment of Congress's full objectives under [a] federal Act" that imposed some economic sanctions on Burma and gave the President discretion to impose more. 530 U.S. at 373. The Massachusetts law, the Court explained, by "imposing a different, state system of economic pressure against the Burmese political regime," could "blunt the consequences of discretionary Presidential action," id.at 376.

This case is very different. Although the Washington Principles and Terezin Declaration both "encourage[]" nations "to develop... alternative dispute resolution mechanisms for resolving ownership issues," Washington Principles 911 , neither requires that the alternative mechanisms be exclusive or otherwise "takes an explicit position in favor of or against the litigation of claims to Nazi-confiscated art." Brief of United States as Amicus Curiae at 18, Saher v. Norton Simon Museum of Art at Pasadena, 131 S. Ct. 3055 (2011) (No. 09-1254), 2011 WL 2134984, at *18. Unlike in Garamendi, where the President promised to seek "dismissal on any valid legal ground," 539 U.S. at 406 (internal quotation marks omitted), or in Crosby, where the state law at issue "blunt[ed]" the force of discretion Congress had explicitly granted the President, 530 U.S. at 376, here, as the district court explained, there is no "direct conflict between the propertybased common law claims raised by Plaintiffs and [United States] foreign policy," Philipp, 248 F. Supp. $3 d$ at 78.

Indeed, far from adopting, as in Garamendi, an "express federal policy," 539 U.S. at 425, of disfavoring domestic litigation of Nazi-era art-looting claims, the United States has repeatedly made clear that it favors such litigation. Congress, as explained above, see supra at 8 , recently extended statutes of limitation for Nazi-era art-looting claims, see HEAR Act § 4, and the FSIA exempts them from the jurisdictional immunity otherwise afforded certain art collections temporarily exhibited in the United States, see 28 U.S.C. § 1605(h)(1)-(3).

V.

For the foregoing reasons, we affirm the district court's denial of the motion to dismiss, except that on remand, the district court must, as required by Simon and de Csepel, grant the motion to dismiss with respect to the Federal Republic of Germany.

So ordered. 